\title{
Innovation and Performance of Tunisian Banks
}

\author{
Samout Ammar \\ Researcher in Finance and Accounting Methods, University of Sfax, Sfax, Tunisia
}

\section{Email address:}

ammarbanq@yahoo.frs

\section{To cite this article:}

Samout Ammar. Innovation and Performance of Tunisian Banks. International Journal of Economics, Finance and Management Sciences. Vol. 4, No. 2, 2016, pp. 87-92. doi: 10.11648/j.ijefm.20160402.18

Received: March 1, 2016; Accepted: March 9, 2016; Published: March 24, 2016

\begin{abstract}
Several studies in the economic field are interested to the factors that influence the performance bank (Mabrouk and Mamoghli, 2010; Gurhan, Gunduz, Kemal and Lutfihak, 2005). The purpose of our work is to check the compatibility of these results, the Tunisian context and this, through the analysis of the characteristics of the Tunisian banks and their impacts on the performance. For has this problem, of descriptive analysis and econometric techniques have been conducted on a sample of Tunisian banks either 110 observations. The result of the model shows that the sign of connection between the size, diversification and the dependent variable (ROE) are statically significant (with the exception of financial resources and level of competition).
\end{abstract}

Keywords: Performance, Diversification, Competition, Size

\section{Introduction}

Each, researcher, a manager or an economist, has become aware of the role of the characteristics of the banks (size, financial resources etc). The economic development. In the light of the importance of the Bank in the development of pay, the concept of performance of banking is become a theme of important research. It is widely treaty in the literature, but there is only a little knowledge developed in which is really this concept.

In this regard, the banking innovation is still a phenomenon little discussed in the literature, and especially at the level of the Tunisian banks, and the previous work on this theme does not give to the Researchers of the techniques sufficient to deal with it.

The underlying idea of our study is to determine the impact of financial innovation on the performance of the banks of Tunisian deposits. It is to identify the specific characteristics that the banks must have so that they can adapt to changes in the environment in the area of financial innovation

The object of this paper will therefore be to examine the relations that can exist between the characteristics of the banks and the financial performance.

As a result of this finding, the questions to which we will try to provide a response to the end of this research is:

- How the characteristics of banks (size, financial resources, etc.) they affect their performance?

- The results obtained allow-they ensure the growth and competitiveness of the banks?

\section{Framework of Analysis and Assumptions}

According to the literature, financial innovation represents a strategic issue which aims to seize the opportunities that technology offers. Innovation plays a crucial role because of its potential to improve the efficiency and profitability of enterprises. It allows to improve the competitiveness for the quasi-totality of the activities of production and service as well as the development of the financial sector that will have direct and positive effects on the economy. Of this fact, the majority of theoretical work that focus on the study of the impact of financial innovations on the performance of the banks are based on three theories: the theory of the Constraint outcome of the work of Silber (1975) and Kane (1983), the theory of the application of the characteristics outcome of the work of Lancaster (1971) and Desai and Low (1987) and finally the theory of contestable markets outcome of the work of Baumol (1982). These work provide an explanation of financial innovation as a factor contributing to the performance of the Bank.

According to the literature of the size of the Bank is an 
important factor for the adoption of financial innovation, financial institutions in large sizes are more able to pay their fixed costs related to the development of new technologies. A second argument in favor of the positive impact of a large size is the existence of imperfections in the financial statements of the market. In fact, the availability of internal funds is important in large enterprises because it will allow to finance investments related to the innovation process, Galande and Fuente (2003). In addition, Dow (2007) explains the influence of size on the decision of the adoption of the Internet and the PC by the caisses banking. It shows that large firms have easier access to external financing.

De Jonghe (2010) shows that small banks are more able to withstand difficult economic conditions, while Barros et al. (2007) argue that the small banks have more chance to obtain good performance and less likely to obtain

In addition, the study of the Buzzacchi and Al. (1995) confirms the positive effect of size on the distribution of new technologies such as the ATM (automatic teller machine).

In the light of the previous discussion, we can conclude that the size can influence the performance of the Bank. The size is measured by the logarithm of the average of the total assets of the Bank.

We can then test the hypothesis $\mathrm{H} 1$ as follows:

H1: The size has a positive effect on the performance of the banks

The financial resources play a key role since they allow the company not only to provide the necessary inbound to innovation but also to absorb the costs of innovation as well as the losses resulting from the potential failures and innovative projects, Telsaz et al. (2003). According to the various research it appears that the bank which uses very substantial financial resources is more likely to adopt innovations financial and in terms of either products or even in terms of process.

In addition, Nana (2009) indicates when the study of the effect of prudential regulation on the performance of the banking system in Cameroon, that the strengthening of the policy of credit increases the banking profits. This means that, the more the Bank grants loans, more income increases and consequently the profit also. In another registry of analysis, the policy of credit can sometimes impede the banking profitability, in particular when an expansionary policy of credit is incompatible with the strategy pursued in research of financial resources.

In the light of the previous discussion, we can conclude that the size can positively influence the performance of the Bank. The size is measured the average of the net profits of the Bank.

We can then test the hypothesis $\mathrm{H} 2$ next:

H2: The financial resources positively affects the performance of the banks

Most of the researchers have demonstrated the existence of a negative relationship between financial innovation and the level of diversification. Boot and Thakor (1997) show that, in a universal bank, financial innovation is less than those of a financial system where the commercial banks and investment are functionally separated. They infer from that that the natural tendency of a universal bank is less innovative.

The model of Kanatas (2003) is based on the fact that these are the magnitudes of the economy (low cost information, economies of scale and even the range of products offered on the market) that motivate the banking integration in its activities that this is the credit or the issuance, which leads to the reduction of innovation in the industry where there is integration of financial services.

In the light of the previous discussion, we can conclude that the diversification can positively influence the performance of the Bank. We can then test the hypothesis $\mathrm{H} 3$ next:

H3: diversification enhances the performance of the banks

Several research shows a positive relationship between competition and innovation. According to Schumpeter (1950) a strong rivalry in the market encourages the banks to innovate in order to increase their competitive advantage. In a study on the banking sector from 11 countries of Latin America, Yildirim and Philippatos (2007) indicate that a rivalry in the market pushes the banks to engage in a differentiation of their products offered and allows the stimulation of financial innovation.

Demsetz (1973) and Peltzman (1977) have shown that the efficiency can determine the competitive behavior of the banks. According to the latter, the companies or the banks more efficient, are supposed to earn more profits, which allows them to have more market share, where the orientation toward a less competitive market.

In the light of the previous discussion, we can conclude that the competition can positively influence the performance of the Bank. The size is measured the average of the net profits of the Bank. To determine the level of competition on the market, one uses the indices of concentration to know the Herfindahl-Hirshman Index. The latter is used as a possible indicator of market power or the concurrence exercise between companies. It is a measure of the concentration of the market by summing the squares of the market shares of all the firms in the sector.

$$
H=\sum_{i=1}^{n} s_{i}^{2}
$$

Where $\mathrm{S} i$ is the market share of the company, $i$ and $n$ is the number of companies. According to the formula defined above, the HHI varies between $(1 / \mathrm{n})$ and 1 with $n$ the number of companies on the market. The more the HHI of a sector is strong, the more competition is concentrated.

We can then test the hypothesis H4 Next

H4: Competition has a positive effect on the performance of the banks.

\section{Research Methodology}

The review of the literature has shown a strong growth of the study on the impact of financial innovation on the performance of banking, but are little studies interested in the subject of the banks in the African context and especially the 
context of Tunisia. This study was chosen in order to highlight the importance of the characteristics of the Tunisian banks and their impacts on the financial performance.

The collection of data has been carried out by referring to the report of the basis of the banks listed (Amen Bank, ATB, Attijari Bank, BH, BIAT, BNA, BT, BTE, STB, UBCI, and UIB) published by the Council of the financial market (CMF), the Bourse of securities (Tunisian BVMT) and the professional association of banks of Tunisia (APBT). As well,

$$
Y_{i}=a_{0}+a_{1} X_{i 1}+a_{2} X_{i 2}+\cdots+a_{p} X_{i p}+\varepsilon_{i}, \quad i=1, \ldots, n
$$

With: $\varepsilon_{i}$ is the error of the model which expresses, or summarizes, the missing information in the linear explanation of the values of $\mathrm{Y}_{\mathrm{i}}$ from $\mathrm{X}_{\mathrm{i} 1}, \ldots ; \mathrm{X}_{\mathrm{ip}}$ (problem of specifications, variables not taken into account, etc.).

Of this fact, our model is as follows

$$
\mathrm{ROE}=\mathrm{A}_{0}-\mathrm{A}_{1} \mathrm{SIZE}+\mathrm{a}_{2} \text { FIN.RES }+\mathrm{a}_{3} \mathrm{DIV}+\mathrm{a}_{4} \mathrm{COMP}+\varepsilon_{i}
$$

\section{Discussion of Results}

The table below shows that on average, the financial profitability of our sample is $(-3,36 \%)$. The banking system of Tunisia presents an average of concentration to a level of $12.2 \%$.

Also, one finds that there is presence of hétérosédasticité (the distribution does not follow a normal law) for all variables except that of size. In other term, it rejects the assumption of normality $\mathrm{H} 0$ for all variables except the variable size.

Table 1. Descriptive Statistics.

\begin{tabular}{llllll}
\hline & ROA & SIZE & FIN.RES & DIV & COMP \\
\hline Mean & -0.0336 & 2,140 & 14.352 & -0.078 & 12.23 \\
Median & 0.124 & -0.260 & 14.426 & 0.017 & 12.52 \\
Maximum & 1.672 & 141.698 & 41.380 & 0.004 & 11.36 \\
Minimum & -8.439 & -258.325 & -40.569 & -1.526 & 10.354 \\
Sum Sq.Dev. & 159.201 & 158642.2 & 245685.32 & 6.259 & 158975.30 \\
Std. Dev. & 1.125 & 30.259 & 12.875 & 0.365 & 0.325 \\
Skewness & -7.658 & 3.365 & -2.265 & -7.425 & 3.865 \\
Kurtosis & 62.243 & 26.310 & 26.215 & 50.352 & 11.312 \\
Jarque Bera & 20985.41 & 4356.20 & 2650.025 & 14985.63 & 375.282 \\
No. observ & 110 & 110 & 110 & 110 & 110 \\
\hline
\end{tabular}

The results obtained at the end of the estimate of the proposed model is postponed in the table (2). The method used is the one on data from the panel. Thus, based on the table (2), we note that the explanatory power of this model is acceptable ( $\mathrm{R}$ adjusts $=0.3552$ ) and their overall significance can reject the null hypothesis which stipulates that the coefficients are all zero $(\mathrm{F}=6.1452 \mathrm{P}<0.05)$. The result of the model shows that the sign of connection between the size, diversification and the dependent variable (ROE) are statically significant (with the exception of financial resources and level of competition). the interval of study is 10 years covering the period from 2005 to 2014 saw that the number of banks is relatively small. This gives a panel of 110 comments

The explanatory variables included in the model relate to the characteristics of the Tunisian banks. The objective of our empirical investigation is to measure the impact of human capital on the innovative behavior of Tunisian SMES. We consider the following model:
Table 2. Analysis by regression.

\begin{tabular}{lllll}
\hline & Coefficient & Std. Error & T-Statistic & Prob \\
\hline SIZE & 2.303747 & 0.466747 & 4.826523 & 0.0012 \\
FIN.RES & -0.424275 & 2.118607 & -1.121458 & 0.124 \\
DIV & 0.439036 & 0.142202 & 3.087403 & 0.0025 \\
COMP & 3.846619 & 10.30725 & 0.310190 & 0.5213 \\
R $^{2}$ & 0.40563 & & \\
R $^{2}$ adj & \multicolumn{3}{c}{0.3652} & \\
F. Statistics & \multicolumn{3}{c}{6.1458} \\
\hline
\end{tabular}

According to the literature, the size of the Bank, measured by the logarithm of total assets, is positively correlated with its financial performance. The results of the estimates are broadly consistent with this hypothesis. In effect, the coefficient of this variable is statistically significant. In addition, the sign obtained is in consistency with the financial literature according to which a bank of large size is generally characterized by a higher performance level compared to the banks of small size. Even our results are consistent with the work of Mabrouk and Mamoghli (2010) and Ben Naceur (2003) in their studies on the performance of the Tunisian banks. In addition, Short (1979), Smirlock (1985), Bikker et al. (2002) and Pasiouras et al. (2007) suggested several arguments to justify the positive effect of size on the performance:

- An important size allows you to reduce costs because of economies of scale that this entails.

- The banks of significant size may also raise capital at a lower cost.

Regarding the variable "financial resource", the results obtained indicate that their coefficient is not significant. Our results show that the coefficient of this variable is a negative sign, either (-0.424) which is not consistent with the hypothesis proposed. The jobs that are confused in our results are very rare. Mabrouk and Mamoghli (2010) found this same result and they have stressed that this negative significance can be found only in the case of imitation of an innovation process.

In another registry of analysis, the diversification at the level of the products and/or services offered by the Tunisian banks has a significant positive impact (the threshold of 5\%) on the financial profitability. As well, diversification strategies continue to be put in place in the field of banking and Tunisian banks choose this concept in order to expand their range of products and services to respond to the financial needs of the clientele. Our results conform to those of Chatti (2010), which 
emphasizes: "We should not put all its eggs in the same basket", that is to say that it would be better to distribute its assets to avoid losing a single cost.

In addition, the results obtained show that there is a relationship not significant between the level of concentration of the banking system of Tunisia as measured by the HHI index and the share of the market. According to the Table 2, we note that the variable $\mathrm{HHI}$ is not significant to the threshold $5 \%,(0.028)$.

\section{Conclusion}

We have tried through this research to explain to analyze the link between financial innovation and the performance of the banks of deposits in Tunisia, using determinants, based on financial performance.

First of all, this research has allowed to cross the inputs of theoreticians and practitioners on the performance of the banks in order to inform the relationship between the financial innovations and the financial performance of banks Financial Tunisian taking into account internal and external factors of the bank which are likely to affect this relationship

The empirical analysis was conducted on a sample composed of 11 banks Tunisian Commercial sides on the stock exchange and observed on the period 2005-2015. The result of the model shows that the sign of connection between the size, diversification and the dependent variable (ROE) are statically significant (with the exception of financial resources and level of competition).

\section{References}

[1] Amblard, M. (2007), «Performance financière: vers une relecture critique du résultat Comptable», XVIème Conférence de l'Association Internationale de Management Stratégique (AIMS), Vol. 2, pp. 61-109.

[2] Athanasoglou, P. Brissimis, S. Delis, M. (2008), «Bank-specific, industry-specific and macroeconomic determinants of bank profitability», Journal of International Financial Markets, Vol. 2, pp. 121-136.

[3] Baltagi, B. H. (2001), «Econometric Analysis of Panel Data», Journal of Banking \& Finance, Vol.4, pp. 19-42.

[4] Barros, C. Ferreira, C. Williams, J. (2007), «Analysing the determinants of performance of best and worst European banks: A mixed logit approach», Journal of Banking \& Finance, Vol. 31, pp. 1942-1980.

[5] Beck, T. Demirgüç-Kunt, A. Levine, R. (2006), «Bank concentration, competition, and crises: first results», Journal of Banking and Finance, Vol. 30, pp. 70-110.

[6] Ben Fredj, I. (2004), «La performance du secteur bancaire tunisien à l'épreuve des transitions de l'activité des banques ", Journal Officiel de la République Tunisienne Vol. 8, pp. 1-27.

[7] Ben Naceur, S. (2003), «The determinants of the Tunisian banking industry profitability: panel evidence», Frontiers in Finance and Economics, Vol. 5, pp. 1-39.
[8] Bernardo, B. et Kassa, W. (2004), «The Dynamics of Product and Process innovation in UK Banking», International Journal of Financial Services Management, Vol. 1, pp. 1-25.

[9] Bikram, D. (2003), «Ownership effects on bank performance: a panel study of Indian banks», Journal of Comparative Economics, Vol. 2, pp. 1-28.

[10] Boone, J. et Van Dijk, T. (1998), «Competition and innovation», Economist 146, Vol. 3, pp. 445-461.

[11] Bourguignon, A. (2000), «Performance et contrôle de gestion», Encyclopédie de Comptabilité, Economica, Vol. 1, pp. 931-941.

[12] Boot, A. et Thakor, A. (1997), «Banking scope and financial innovation», The review of financial studies, Vol, 10, No, 4, pp. 1990-1131.

[13] Buzzachi, L. Colombo, G. et Mariotti, S. (1995), «Technological regimes and innovation in services: the case of the Italian banking industry», Research Policy, Vol. 24, pp. 151-168.

[14] Chaffai, M. (1998), «Estimating Input-Specific Technical Inefficiency: The Case of the Tunisian Banking Industry», European Journal of Operational Research, Vol 98, pp. 314-33.

[15] Christine, Z. (2006), «L'innovation et les marches financiers aux Etats-Unis depuis les années 1970», euro-journal, vol. 4, pp. 160-190.

[16] Cook, W. et Hababou, M. (2000), «The Effects of Financial Liberalization on the Tunisian Banking Industry: A Non-parametric Approach», Working paper, Vol.2, pp. 1-40.

[17] De Jonghe, O. (2010), «Back to the basics in banking? A micro-analysis of banking system stability», Journal of Finance, Vol. 8, pp. 1-41.

[18] Demirgüç-Kunt, A. et Huizinga, H. (2000), «Financial structure and bank profitability», Policy Research Working, The journal of World Bank, Vol. 3, pp. 1-24.

[19] Denis, D. et Sarin, A. 1997, «Agency problems, equity ownership and corporate diversification», The Journal of Finance, Vol. 5, pp. 135-160.

[20] Dietrich, A. et Wanzenried, G. (2011), «Determinants of bank profitability before and during the crisis: Evidence from Switzerland», Journal of Finance, Vol. 8, pp. 1-42.

[21] Djelassi, M. Hakimi, A. et Hamdi, H. (2011), «Single versus multiple bank relationships and firm performance: an econometric model for some Tunisian firms», International research journal of finance and economics, Vol. 3, pp. 46-57.

[22] Djelassi, M. Hakimi, A. et Hamdi, H. (2011), «Financial liberalization and banking profitability: a panel data analysis for Tunisian banks», International Journal of Economics and Financial Issues, Vol 1, pp. 19-32.

[23] Dow, J. (2007), «The adoption of web banking at credit unions», The Quarterly Review of Economics and Finance, vol 3, pp. 435-448.

[24] Ebrahim, M. et Hussain, S. (2010), «Financial development and asset valuation: The special case of real estate», Journal of Banking and Finance, Vol. 4, pp. 150-162.

[25] Frantz, M. (2007), «Diversification, risque et performance financière», Revue Financier, Vol.4, pp. 3-33. 
[26] Frame, W. and White, J. (2004), «Empirical studies of financial innovation: lots of talk, little action?», Journal of Economic Literature, vol.1, pp116-104.

[27] Ferrier, D. et Lovell, C. (1990), «Efficiency of Financial Institutions: International Survey and Directions for Future Research», Journal of Banking and Finance, Vol. 5, pp.2-51.

[28] Fuen, T. Gomez, L. and Polo, J. (2003), «Intrafirm diffusion of new technologies: an empirical application», Research Policy, vol. 32, pp. 533-551.

[29] Gadioux, S. (2010), «relation entre la performance sociétale et la performance financière des organisations », JOURNAL of Economics and Sociology, vol. 36, n², p. 129-146.

[30] Galande, J. and Fuente, J. (2003), «Internal factors determining a firm's innovation behaviour», Research Policy, vol. 3, pp. 715-736.

[31] Goddard, J. Molyneux, P. and Wilson, J. (2004), «The profitability of European banks: a cross-sectional and dynamic panel analysis», Journal of Banking and Finance Vol.72, pp. 363-81.

[32] Gurhan, G. Gunduz, U. Kemal, K. et Lutfihak, A. (2005), «Effects of innovation types on firm performance», Journal of Banking and Finance, Vol. 6, pp. 1-43

[33] Herrera, A. etMinetti, R. (2007), «Informed finance and technological change: evidence from credit relationships», Journal of Financial Economics, vol 83, pp. 223-269.

[34] Indranarin, R. (2009), «Bank- specific, industry-specific and macroeconomic determinants of profitability in Taiwanese banking system: under panel data estimation», International research journal of finance and economics, Vol. 34, pp. 1450-2887.

[35] João Tovar, J. (2010), «How to measure innovation? New evidence of the technology- growth linkage», Journal of Research in Economics, Vol. 64, pp. 81-96.

[36] Josh, L. (2003), «The new new financial thing: the origins of financial innovation», Journal of Research in Economics, Vol. 6, pp. 1-55.

[37] John, P. Bonin, H. and Paul, W. (2003), «Bank performance, Efficiency and Ownership in Transition Countries», Journal of Banking and Finance, Vol.5, pp. 1-35.

[38] Kamilia, L. et Abdelkader, C. (2009), «Structure de propriété et performance financière $=$ : cas des banques de dépôts en Tunisie», revue financier, Vol. 1, pp. 1-31.

[39] Kasman, A. (2010), «Consolidation and Commercial bank net interest margins: evidence from the old and new European Union members», journal Economic Modelling, Vol. 3, pp.3-56.

[40] Khemakhem, (1976), «dynamique de contrôle de gestion», Journal économique, Vol 2, pp.46-76.

[41] King and Levine, (1993), «Finance and growth», The Quarterly Journal of Economics, Vol 108, pp. 717-737.

[42] Laporta, R. Lopez-de-Silanes, F. et Shleifer, A. (2002), "Government ownership of commercial banks», Journal of Finance, Vol 5, pp. 1-25.

[43] Lieven, B. Olivier, D. and Rudi, V. (2006), «Does the stock market value bank diversification? », journal of banking and finance, Vol.3, pp, 1999-2023.
[44] Lofts, C. and Loundes, J. (2000), «Foreign ownership, foreign competition and innovation in Australian enterprises», Working Paper, Vol.2, pp. 1-25.

[45] Love, J. Ashcroft, B. and S. Dunlop, (1996), «Corporate structure, ownership and the likelihood of innovation», Journal of Banks and Bank Systems, vol 28, pp. 737-746.

[46] Mabrouk, A. etMamoghli, C. (2010), «Is financial innovation influenced by financial liberalization? Evidence from the Tunisian banking industry», Journal of Banks and Bank Systems, Vol 5, Issue 3, pp. 97-111.

[47] Mabrouk, A. etMamoghli, C. (2010), «Dynamic of financial innovation and performance of banking firms: context of an emerging banking industry», International research Journal of Finance and Economics, Vol. 51, pp. 17-36.

[48] Mamoghli, C. et Dhouibi, R. (2007), »Quel est l'impact de la propriété publique sur la rentabilité des banques? cas des banques tunisiennes«, Revue financier, Vol.3, pp. 1-28.

[49] Marmuse, C. (1997), " la performance », Encyclopédie de gestion, Economica, Vol, 2.

[50] Micco, A. Panizza, U. et Yanez, M. (2007), «Bank ownership and performance, Does politics matter?», Journal of Banking and Finance, Vo 31, pp. 219-241.

[51] Mohamed, T. et Ben romdhane S. (2008), «Impact de la technologie sur les activités bancaires tunisiennes », Revue financier, Vol.2, pp. 1-20.

[52] Mohieddine, R. Mohamed, A. et Murat, Y. (2010), "Characteristics of innovating firms in Tunisia: The essential role of external knowledge sources», Journal of Structural Change and Economic Dynamics, Vol 21, pp 181-196.

[53] OECD (2007), «innovation and growth: rational for an innovation strategy», euro-journal, vol. 3, pp 2-29.

[54] Olivier, V. (2001), «Le concept de performance et sa mesure: un état de l'art», Cahiers de recherche, Vol. 2 pp. 1-18.

[55] Pasiouras, F. Kosmidou, K. (2007), «Factors influencing the profitability of domestic and foreign commercial banks in the European Union», Journal of Finance, Vol2, pp 1-24.

[56] Patricia, L. Benjamin, M. (2010), «Determinants of bank efficiency: The case of Brazil», Journal of Operational Research, Vol 207, pp1587-1598.

[57] Philipp, K. (2008), «The relationship between technology, innovation, and firm performance: empirical evidence from e-business in Europe», Journal of Research Policy, Vol 37, pp. 1317-1328.

[58] Porter, M. (2004), «Competitive strategy», New York edition, Journal of Research Policy, Vol. 2, pp. 1-6.

[59] Saîdane, D. (2001), « La banque traditionnelle est-elle en déclin? », Séminaire ayant eu lieu à la FSEGT.

[60] Sghaier, A. (2009), «La relation entre la concurrence et l'effecience bancaire: cas des banques commerciales tunisiennes», colloque du GDRI DREEM "Innovation et développement dans les pays méditerranéens / Innovation and development in the Mediteranean countries", Le Caire, Egypte, 13-14 décembre 2010.

[61] Silbert, W. (1975), «The process of financial innovation», American economic review, Vol.73, n², pp. 131-161. 
[62] Stiroh, K. et Rumble, A. (2006), «The dark side of diversification: The case of US financial holding companies», Journal of Banking and Finance, Vol 30, pp. 2131-2161.

[63] Tazarki, W. (2002), « Mesure de l'efficacité opérationnelle des banques: Application pour les banques commerciales tunisiennes ».

[64] Tufano, P. (2002), «Financial innovation», Journal of corporate Finance, Vol. 13, pp. 1-44.
[65] Walker, R. (2004), «Innovation and organizational performance: Evidence and a research agenda», Journal of Research Policy, Vol. 2, pp. 1-26.

[66] Yildirim, H. and Philippatos, C. (2007), «Restructuring consolidation and competition in Latin American banking markets», Journal of Banking and Finance, vol 31, pp. 629-639. 